\title{
Genome-Wide Identification of Reference Genes for Reverse-Transcription Quantitative PCR in Goat Rumen
}

\author{
Juan Zhao ${ }^{\dagger}$, Cheng Wang ${ }^{\dagger}$, Lin Zhang, Aiai Lei, Linjie Wang ${ }^{\circledR}$, Lili Niu, Siyuan Zhan ${ }^{\circledR}$, Jiazhong Guo, \\ Jiaxue Cao, Li Li $\mathbb{B}$, Hongping Zhang $\mathbb{( 1 )}$ and Tao Zhong *
}

check for

updates

Citation: Zhao, J.; Wang, C.; Zhang, L.; Lei, A.; Wang, L.; Niu, L.; Zhan, S.; Guo, J.; Cao, J.; Li, L.; et al.

Genome-Wide Identification of Reference Genes for

Reverse-Transcription Quantitative PCR in Goat Rumen. Animals 2021, 11, 3137. https://doi.org/10.3390/

ani11113137

Academic Editor: Changxi Li

Received: 8 October 2021

Accepted: 30 October 2021

Published: 2 November 2021

Publisher's Note: MDPI stays neutral with regard to jurisdictional claims in published maps and institutional affiliations.

Copyright: (c) 2021 by the authors. Licensee MDPI, Basel, Switzerland. This article is an open access article distributed under the terms and conditions of the Creative Commons Attribution (CC BY) license (https:/ / creativecommons.org/licenses/by/ $4.0 /)$.
Farm Animal Genetic Resources Exploration and Innovation Key Laboratory of Sichuan Province, College of Animal Science and Technology, Sichuan Agricultural University, Chengdu 611130, China; 2020202035@stu.sicau.edu.cn (J.Z.); wxx79595@163.com (C.W.); z109031111@163.com (L.Z.); sicaulei@163.com (A.L.); wanglinjie@sicau.edu.cn (L.W.); niulili@sicau.edu.cn (L.N.); siyuanzhan@sicau.edu.cn (S.Z.); jiazhong.guo@sicau.edu.cn (J.G.); jiaxuecao@sicau.edu.cn (J.C.); lily@sicau.edu.cn (L.L.); zhp@sicau.edu.cn (H.Z.)

* Correspondence: zhongtao@sicau.edu.cn

† These authors contributed equally to this work.

Simple Summary: The rumen plays an essential role as a digestive organ and serves as the primary site of energy substrate absorption for the productive ruminants. Understanding gene expression profiles is necessary to explore the intrinsic regulatory mechanisms of rumen development in goats. The selection of suitable reference genes (RGs) was the primary assay before the real-time quantitative PCR (RT-qPCR). We identified sixteen genome-wide candidate RGs for normalization of gene expression assessments in goat rumen tissues. We demonstrate that the RGs selected (RPS4X and RPS6) were more stably expressed than the commonly used HKGs (ACTB and GAPDH) in goat rumen tissues, suggesting that the ribosomal protein gene family may be another source for the RG pool.

Abstract: As the largest chamber of the ruminant stomach, the rumen not only serves as the principal absorptive surface and nutrient transport pathway from the lumen into the animal, but also plays an important short-chain fatty acid (SCFA) metabolic role in addition to protective functions. Accurate characterization of the gene expression profiles of genes of interest is essential to the exploration of the intrinsic regulatory mechanisms of rumen development in goats. Thus, the selection of suitable reference genes (RGs) is an important prerequisite for real-time quantitative PCR (RT-qPCR). In the present study, 16 candidate RGs were identified from our previous transcriptome sequencing of caprine rumen tissues. The quantitative expressions of the candidate RGs were measured using the RT-qPCR method, and the expression stability of the RGs was assessed using the geNorm, NormFinder, and BestKeeper programs. GeNorm analysis showed that the $M$ values were less than 0.5 for all the RGs except GAPT4, indicating that they were stably expressed in the rumen tissues throughout development. RPS4X and RPS6 were the two most stable RGs. Furthermore, the expressions of two randomly selected target genes (IGF1 and TOP2A), normalized by the selected most stable RGs (RPS4X and RPS6), were consistent with the results of RNA sequencing, while the use of GAPDH and ACTB as RGs resulted in altered profiles. Overall, RPS4X and RPS6 showed the highest expression stability and the lowest coefficients of variation, and could be used as the optimal reference combination for quantifying gene expression in rumen tissues via RT-qPCR analysis.

Keywords: caprine; rumen; genome-wide; reference gene; RT-qPCR

\section{Introduction}

The reverse-transcription quantitative real-time polymerase chain reaction (RT-qPCR) is a well-established method for quantifying mRNA expression, in addition to northern blotting, in situ hybridization, and ribonuclease protection assay [1,2]. Compared with 
other technologies, RT-qPCR has the advantages of rapidity, accuracy, high sensitivity, and good reproducibility. Thus, it is extensively used to compare mRNA transcription in different biological samples, tissues, or cells [3,4]. The accuracy of RT-qPCR is primarily dependent on the selection of suitable RGs [5], which act as an internal control for the normalization of the expression of target genes. Perfect RGs should be stably expressed in diverse individuals, tissues, and cells without spatiotemporal differences, even under different experimental treatments [6]. However, several studies have found that the stabilities of RGs turned out to be species-, tissue-, or cell-specific [7,8]. Lee and colleagues revealed considerable variability of 12 commonly used RGs within and across microarray datasets, including in different mammalian cell contexts [9]. Therefore, the screening of suitable RGs is a vital prerequisite to quantifying the expression profiles of target genes.

Commonly used RGs such as GAPDH, ACTB, and ribosomal genes are considered to be expressed continuously and stably during a cell's life activities, and are called housekeeping genes (HKGs) $[1,6,10]$. Sometimes, expressions of HKGs are not very stable or otherwise do not meet the criteria for a suitable internal control [11]. For instance, GAPDH and ACTB were found to not be expressed stably in the skeletal muscle of growing mice, although they were used as the single RG in more than $90 \%$ of the quantification studies [1]. More than one RG shoud be used to normalize the expressions of target genes. More candidate novel HKGs, predominantly ribosomal protein genes, were identified by a meta-analysis of more than 13,000 samples in humans [12]. The phenomenon was reported that a more significant expression error was commonly associated with increased noise and inability to detect minor differences [13]. Besides RNA yield, quality, and reverse transcription efficiency $[4,7,14]$, it is also necessary to apply a data normalization strategy to eliminate the variations caused by technology or experiment. At present, the geNorm, NormFinder, and BestKeeper software tools are primarily used to evaluate the expression stability of candidate RGs, and to identify the minimum number of RGs needed under diverse experimental conditions $[15,16]$.

Extensive studies have been conducted to explore the mechanisms of digestion and absorption of nongrain feed in ruminants in order to improve the feed conversion efficiency, especially for pigs and chickens [17-19]. As a unique digestive organ, the rumen is the main chamber for the absorption and transportation of nutrients, providing approximately $70 \%$ of energy for ruminants [20]. Numerous studies have pointed out the main mechanisms related to the absorption and transport of nutrients, such as passive diffusion [21], acid anion exchange [22], proton-coupled volatile fatty acid (VFA) transport [23], and electrically mediated VFA transport [20]. Many candidate genes and noncoding RNAs have been investigated to explore their functions during rumen development [24-28]. Therefore, the selection and validation of RGs are necessary prior to assessing the expression levels of candidate genes without bias.

In the literature, a limited number of candidate RGs (ACTB, UXT, DBNDD2, RPS9, $D D X 54$, and $H M B S$ ) have been validated to be expressed stably in the rumen epithelial tissues of cattle [29]. Recently, more novel RGs were identified and validated to be more stable than the traditional HKG in the skin tissues of Chinese indigenous goats based on high-thoughput sequencing technology [30]. Thus, we conducted a genome-wide search for RGs in goat rumen tissues using our previous RNA-sequencing data. In the present study, 16 candidate RGs were selected and quantified for their expression levels using RT-qPCR. Subsequently, the stability and applicability of these RGs were evaluated using geNorm, NormFinder, and BestKeeper procedures to determine the optimal RGs in goat rumen tissues.

\section{Materials and Methods}

\subsection{Animals, RNA Isolation, and $c D N A$ Synthesis}

In this study, 12 Chengdu Brown goats [31] (six 2-month-old goats and six 1-year-old goats) were randomly selected in the Chengdu Xilingxue Agricultural Development Co., Ltd. (Sichuan, China). All the goats were reared according to the local standards of Sichuan 
Province (DB51/T654-2007). After slaughter, rumen samples were collected rapidly, placed in $2 \mathrm{~mL}$ cryogenic tubes without RNA enzyme, and immediately frozen in liquid nitrogen.

Total RNA was extracted using the Animal Total RNA Isolation Kit (FOREGENE, Chengdu, China) according to the methods described by the manufacturers. The purity and integrity of RNA were evaluated using $1.0 \%(w / v)$ agarose gel electrophoresis and an Agilent 2100 Bioanalyzer System (Agilent, Santa Clara, CA, USA). The concentration of RNA was measured using the NanoDrop 2000 spectrophotometer (Thermo Scientific, Waltham, MA, USA). The cDNA was synthesized using the Reverse Transcription Kit (Takara, Dalian, China) following the producer's protocol. The synthesized cDNA was stored at $-20^{\circ} \mathrm{C}$.

\subsection{Genome-Wide Selection of the Candidate RGs}

An appropriate RG should not only be expressed stably between tissues and biological states, but also have a higher level than the background [14]. Based on our RNA-sequencing data of 12 goat rumen tissues (PRJNA720177), the candidate genes were preliminarily selected according to the three parameters (fragments per kilobase of exon model per million mapped reads (FPKM), FDR, and CV). The FPKM value was greater than 100 and the absolute fold change of log2-converted absolute FPKM less than 1, the false discovery rate (FDR) was less than 1, and the coefficient of variation (CV) was less than 0.2 . Subsequently, eight genes involved in the ribosome, aminoacyl-tRNA biosynthesis, and HIF-1 signaling pathways were selected as the candidate RGs (Table S1). In addition, another eight previously reported RGs were jointly analyzed in this study, including the two most used RGs (ACTB and GAPDH).

\subsection{Quantitative Real-Time PCR (RT-qPCR) and Amplification Efficiency}

The qPCR primer pairs of the tested RGs were designed using the Primer Premier 5.0 software (PREMIER Biosoft, Palo Alto, CA, USA) (Table 1). The primers were synthesized by Sangon Biotech (Shanghai) Co., Ltd. The RT-qPCR was performed in a $10 \mu \mathrm{L}$ system, including $5 \mu \mathrm{L}$ SYBR Green Real-Time PCR Master Mix (Takara, Dalian, China), $0.4 \mu \mathrm{L}$ each of forward and reverse primer $(10 \mu \mathrm{M}), 3.4 \mu \mathrm{L}$ RNase-free $\mathrm{ddH}_{2} \mathrm{O}$, and $0.8 \mu \mathrm{L}$ cDNA. The cycling conditions were as follows: $3 \mathrm{~min}$ at $94^{\circ} \mathrm{C}$ for enzyme activation, followed by 35 cycles of $30 \mathrm{~s}$ at $95^{\circ} \mathrm{C}$ and $30 \mathrm{~s}$ at $56.9^{\circ} \mathrm{C}$ or $59.4{ }^{\circ} \mathrm{C}$ for annealing, $1 \mathrm{~min}$ at $72{ }^{\circ} \mathrm{C}$, and final extension for $7 \mathrm{~min}$.

Table 1. The primer sequence information, standard curve amplification efficiency, and $R^{2}$ values used in this study.

\begin{tabular}{|c|c|c|c|c|c|c|c|}
\hline Gene & Accession No. & Sequences $\left(5^{\prime}-3^{\prime}\right)$ & $\operatorname{Tm}\left({ }^{\circ} \mathrm{C}\right)$ & Size (bp) & Slope & Efficiency (\%) & $\mathbf{R}^{2}$ \\
\hline RPS20 & XM_013969227.2 & $\begin{array}{l}\text { F: ATCAGAGGCGCGAAGGAAAA } \\
\text { R: TGCAGGTCAATGAGTCGCTT }\end{array}$ & 56.9 & 158 & -3.421 & $96.0 \%$ & 1.000 \\
\hline RPL7 & XM_005689063.3 & $\begin{array}{l}\text { F: ACTTCCTGTGGCCCTTTAA } \\
\text { R: ATCTGGTCTTCCCTGTTGC }\end{array}$ & 56.9 & 103 & -3.489 & $93.5 \%$ & 0.993 \\
\hline RPL3 & XM_005681086.3 & $\begin{array}{l}\text { F: CTGACAAGAGCATCAACCC } \\
\text { R: GAAGCGACCATGACCAAAT }\end{array}$ & 56.9 & 209 & -3.472 & $94.1 \%$ & 0.999 \\
\hline RPS26 & XM_013963957.2 & $\begin{array}{l}\text { F: GAACAACGGTCGTGCCAAAA } \\
\text { R: ACGTAGGCGTCGAAAACACT }\end{array}$ & 56.9 & 171 & -3.431 & $95.6 \%$ & 0.993 \\
\hline$R P S 4 X$ & XM_005700650.3 & $\begin{array}{l}\text { F: TACTTGGCCTCCTCAGGTGT } \\
\text { R: TACTTGGCCTCCTCAGGTGT }\end{array}$ & 59.4 & 223 & 88 & $106.4 \%$ & 0.999 \\
\hline RPS27A & XM_005686612.3 & $\begin{array}{l}\text { F: TCTAGTGTTGAGACTTCGTGGTG } \\
\text { R: CCAGCACCACATTCATCTGAGG }\end{array}$ & 59.4 & 183 & -3.523 & $92.3 \%$ & 0.997 \\
\hline GAPDH & XM_005680968.3 & $\begin{array}{l}\text { F: GCAAGTTCCACGGCACAG } \\
\text { R: GGTTCACGCCCATCACAA }\end{array}$ & 59.4 & 249 & -3.398 & $96.9 \%$ & 1.000 \\
\hline CALM2 & XM_005686574.3 & $\begin{array}{l}\text { F: AGAAGCATTCCGTGTGTTT } \\
\text { R: TCATAGTTTACTTGACCAT }\end{array}$ & 56.9 & 159 & -3.495 & $93.3 \%$ & 0.995 \\
\hline RPS6 & XM_005683632.3 & $\begin{array}{l}\text { F: GGACTGGAGAGAGAAAGCG } \\
\text { R: ACAACATACTGGCGGACAT }\end{array}$ & 59.4 & 211 & -3.324 & $99.9 \%$ & 0.996 \\
\hline FTH1 & NM_001285609.1 & $\begin{array}{l}\text { F: GCTTGGAAAGAAGTGTGAA } \\
\text { R: GCAGGTTGGTTATGTGGTC }\end{array}$ & 56.9 & 153 & -3.364 & $98.3 \%$ & 0.992 \\
\hline
\end{tabular}


Table 1. Cont.

\begin{tabular}{|c|c|c|c|c|c|c|c|}
\hline DYNLL1 & XM_018061128.1 & $\begin{array}{l}\text { F: GCCGTAATCAAGAATGCCGA } \\
\text { R: CGAAGTTCCTCCCCACGATG }\end{array}$ & 56.9 & 172 & -3.285 & $101.6 \%$ & 1.000 \\
\hline KARS & XM_005691813.3 & $\begin{array}{l}\text { F: AATCACAGTGCTGATGATGGCA } \\
\text { R: TCAGCTGGTGGATTGCTTGG }\end{array}$ & 59.4 & 94 & -3.256 & $102.8 \%$ & 0.999 \\
\hline$A C T B$ & XM_018039831.1 & $\begin{array}{l}\text { F: CCTGCGGCATTCACGAAACTAC } \\
\text { R: ACAGCACCGTGTTGGCGTAGAG }\end{array}$ & 59.4 & 87 & -3.223 & $104.3 \%$ & 0.997 \\
\hline YWHAZ & XM_018058314.1 & $\begin{array}{l}\text { F: ACTACTATCGCTACTTGGCTGAG } \\
\text { R: CTTCTTGTTATGCTTGCTGTGA }\end{array}$ & 59.4 & 84 & -3.264 & $102.5 \%$ & 0.998 \\
\hline GPAT4 & XM_018041983.1 & $\begin{array}{l}\text { F: GGAGTCTCCTTTGGTATCCG } \\
\text { R: CCATTGGTGTAGGGCTTGTA }\end{array}$ & 56.9 & 128 & -3.165 & $107.0 \%$ & 0.992 \\
\hline$H M B S$ & XM_005689536.3 & $\begin{array}{l}\text { F: GCAACGGCGGAAGAAGACA } \\
\text { R: CAGCGAGTGAACAACCAGG }\end{array}$ & 59.4 & 267 & -3.316 & $100.3 \%$ & 0.994 \\
\hline TOP2A & XM_005693780.3 & $\begin{array}{l}\text { F: AGCCCATTGGTCAGTTTGGT } \\
\text { R: ACCAATTCCTTCAGCGCCAT }\end{array}$ & 55.0 & 218 & - & - & - \\
\hline$I G F 1$ & XM_005680537.3 & $\begin{array}{l}\text { F: CAGTCACATCCTCCTCGCAT } \\
\text { R: AGAGCATCCACCAACTCAGC }\end{array}$ & 61.3 & 112 & - & - & - \\
\hline
\end{tabular}

$R^{2}$ refers to the correlation coefficient. Generally, $R^{2}>0.98$ is considered feasible and linear by default.

To evaluate the specificity of the designed primers, melting curve analysis and agarose gel electrophoresis were performed to detect the nonspecific product of each primer pair. The standard curve of the qPCR was established using the gradient diluted cDNA. The correlation coefficient and amplification efficiency were calculated using the CFX ManagerTM Software (Bio-Rad, Hercules, CA, USA). The calculation equation for primer amplification efficiency was as follows: $\mathrm{E} \%=\left(10^{(-1 / \text { slope })}-1\right) \times 100 \%$.

\subsection{The Expression Stability of the Candidate RGs in Rumens}

To assess the optimal set of candidate RGs in the rumen tissues, the stability of each RG was analyzed using the geNorm (PrimerDesign, Southampton, Hample, England), NormFinder (Aarhus University Hospital, Aarhus, Denmark), and BestKeeper (Microsoft, Redmond, Washington, DC, USA). The relative expression quantity (Q) of each candidate internal RG was calculated as follows: $\mathrm{Q}=2^{-\Delta \mathrm{Ct}}, \Delta \mathrm{Ct}=\mathrm{Ct}_{\text {(sample) }}-\mathrm{Ct}_{\text {(minimum), where }}$ $\mathrm{Ct}_{\text {(sample) }}$ was the $\mathrm{Ct}$ value of a factor in each sample and $\mathrm{Ct}_{\text {(minimum) }}$ was the minimum $\mathrm{Ct}$ value of this gene in all samples.

The gene expression stability ( $\mathrm{M}$ value) was calculated using geNorm by comparing a particular gene with other RGs [2,32]. The lower the value of M, the better the stability of the RG [33]. By gradually eliminating the RGs with the largest $M$ values, all candidate RGs were ranked and the optimal number of RGs was selected. NormFinder was used to calculate stability values for candidate RGs by analyzing their intragroup and intergroup variation [6,34]. The $R G$ with the lowest stability value was considered to be the most stable gene [35]. BestKeeper was used to analyze the expression stability of candidate RGs by calculating the coefficient of variance (CV) and the standard deviation (SD) based on the raw $\mathrm{Ct}$ values from RT-qPCR [6]. The RGs with the highest stability had the lowest values of $\mathrm{CV}$ and $\mathrm{SD}$, while harboring the highest value of correlation coefficient $(\mathrm{r})$. In addition, two target functional genes (TOP2A and IGF1) were chosen to validate the effects of the different RGs on their expression. All samples were evaluated in triplicate, and their relative expression levels were estimated using the $2^{-\Delta \Delta C t}$ method.

\subsection{Statistical Analyses}

Statistical analyses were conducted using SPSS 20.0 software (IBM, Armonk, NY, USA). All data are expressed as mean \pm SEM; data were compared by one-way ANOVA and Duncan's new multiple range tests, and P-values lower than 0.05 were considered statistically significant. Statistical analysis was performed using the Graph Pad Prism 6.01 program (GraphPad, San Diego, CA, USA). 


\section{Results}

\subsection{The Selection of RGs in Goat Rumen Tissues}

According to the values of FPKM and coefficient of variation, a total of 71 candidate RGs were obtained (Supplementary Table S1). Subsequently, KEGG enrichment analysis showed that most of the 71 candidate RGs were involved in the ribosome, aminoacyltRNA biosynthesis, and HIF-1 signaling pathways (Table S1). Thus, we selected eight representative RGs (RPS20, RPL7, RPL3, RPS26, RPS4X, RPS6, KARS, and RPS27A) to evaluate their expression stability. In addition, five RGs (GPAT4, HMBS, CALM2, DYNLL1, and FTH1) were selected based on previous studies on these rumen tissues. We also used three traditional RGs, including GAPDH, YWHAZ, and ACTB genes.

\subsection{RNA Purity, Primer Verification, and Amplification Efficiency}

The OD260/280 ratios of the RNA samples ranged from 1.81 to 2.12 and their RNA integrity number (RIN) values ranged from 8.1 to 9.1 (Supplementary Table S2), indicating that the isolated RNA was of high quality and suitable for subsequent analysis. As represented in Supplementary Figures S1 and S2, a single band with the expected size was amplified and visualized on the agarose gel, and a single peak was detected in the melting curve of each primer pair, indicating that all the 16 primer pairs could amplify the target fragment with high specificity. In addition, the standard curves of the tested RGs showed better linear relationships, with their efficiency ranging from $92.3 \%$ to $107.0 \%$, and all of the correlation coefficients were higher than 0.98 (Table 1, Supplementary Figure S3).

\subsection{Gene Expression Dispersion Analysis}

The average $\mathrm{C} t$ values of all cDNA samples from candidate internal RGs ranged from 16.74 to 27.08 (Figure 1). The lower the dispersion of the $\mathrm{Ct}$ value, the higher the stability of the gene. Among the candidate genes tested, the transcript abundance was highest for RPS6 (average FPKM, 959.165) and the lowest for HMBS (average FPKM, 6.141). In brief, the lowest $\mathrm{Ct}$ dispersion was observed for RPS27A (17.05 $\leq \mathrm{Ct} \leq 18.30)$, followed by KARS, RPL7, RPS26, and RPS4X, while the highest variation was noted for HMBS $(23.88 \leq \mathrm{Ct} \leq 27.08)$. These results indicated that the most stable gene in terms of mRNA expression levels was RPS27A, while the least stable one was HMBS.

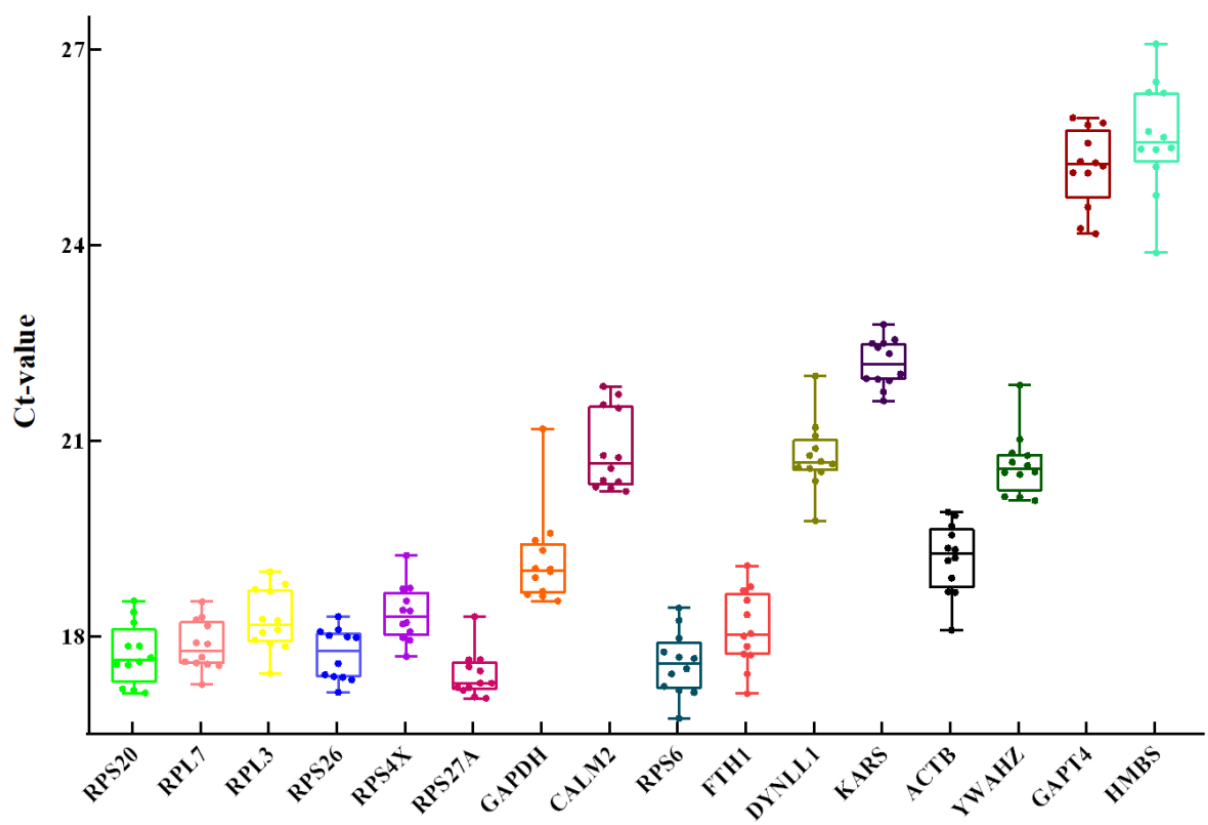

Figure 1. Range and dispersion of Ct values of candidate RGs obtained from all cDNA samples. The ends of each box represent $25 \%$ and $75 \%$ of the quartile range. The line across the box represents the median value. 


\subsection{Expression Stability of the RGs Assessed via geNorm Analysis}

As shown in Figure 2, most of the commonly used RGs displayed acceptably low variability $(\mathrm{M}<0.5)$. RPS4X, RPS6, RPS20, and RPL3 were the most stable genes with the lowest $\mathrm{M}$ values $(\mathrm{M}<0.2)$. Similarly, GAPT4, ACTB, CALM2, HMBS, FTH1, and GAPDH were the least stable genes with the highest $M$ value (Figure 2A). In addition, geNorm was used to calculate the number of optimal RGs to derive the normalization factor (NF). The optimal number of RGs recommended in this experiment by the pairwise-variation analysis (Figure 2B) was two, indicating that the most stable RGs (RPS4X and RPS6) would be sufficient to normalize gene expression among all the rumen samples used in this study.

A Average expression stability values of remaining control genes

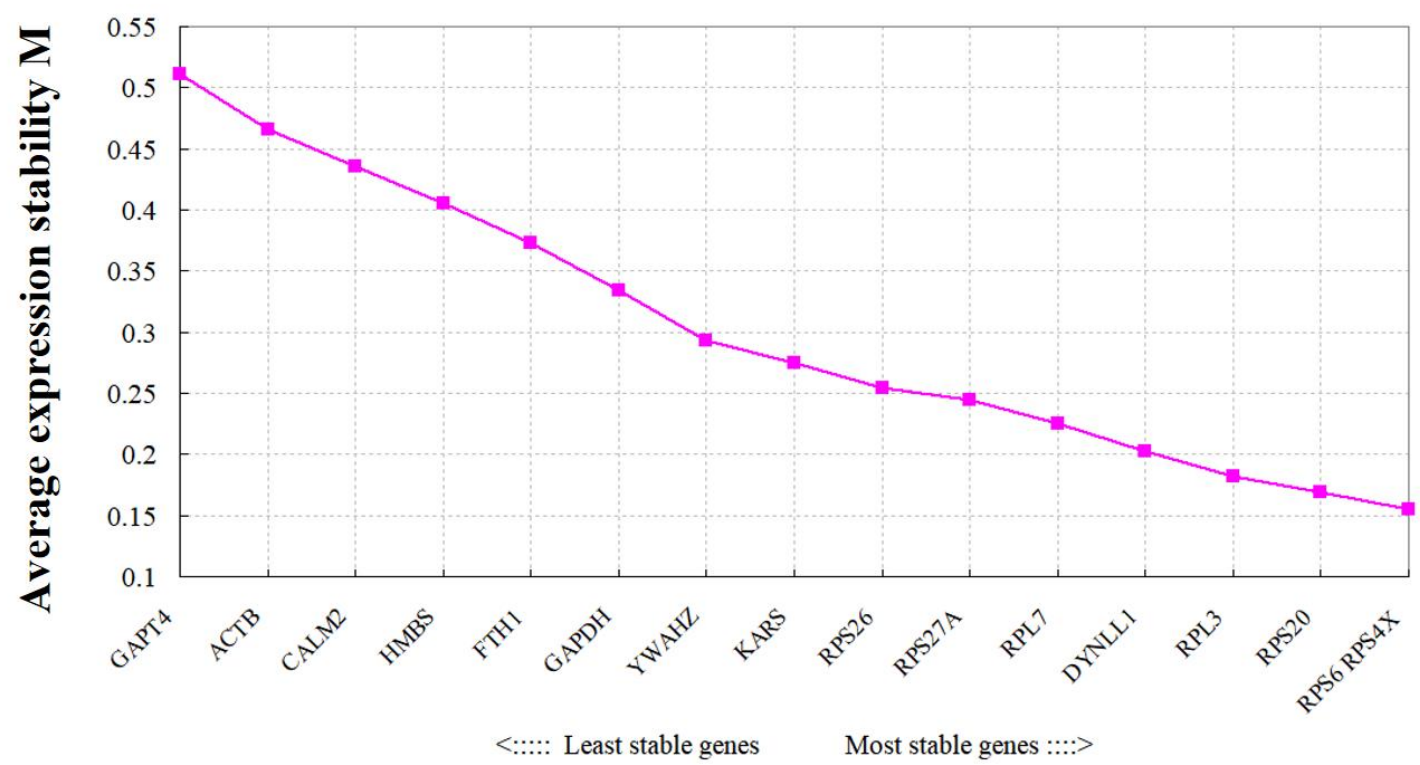

B

Determination of the optimal number of control genes for normalization

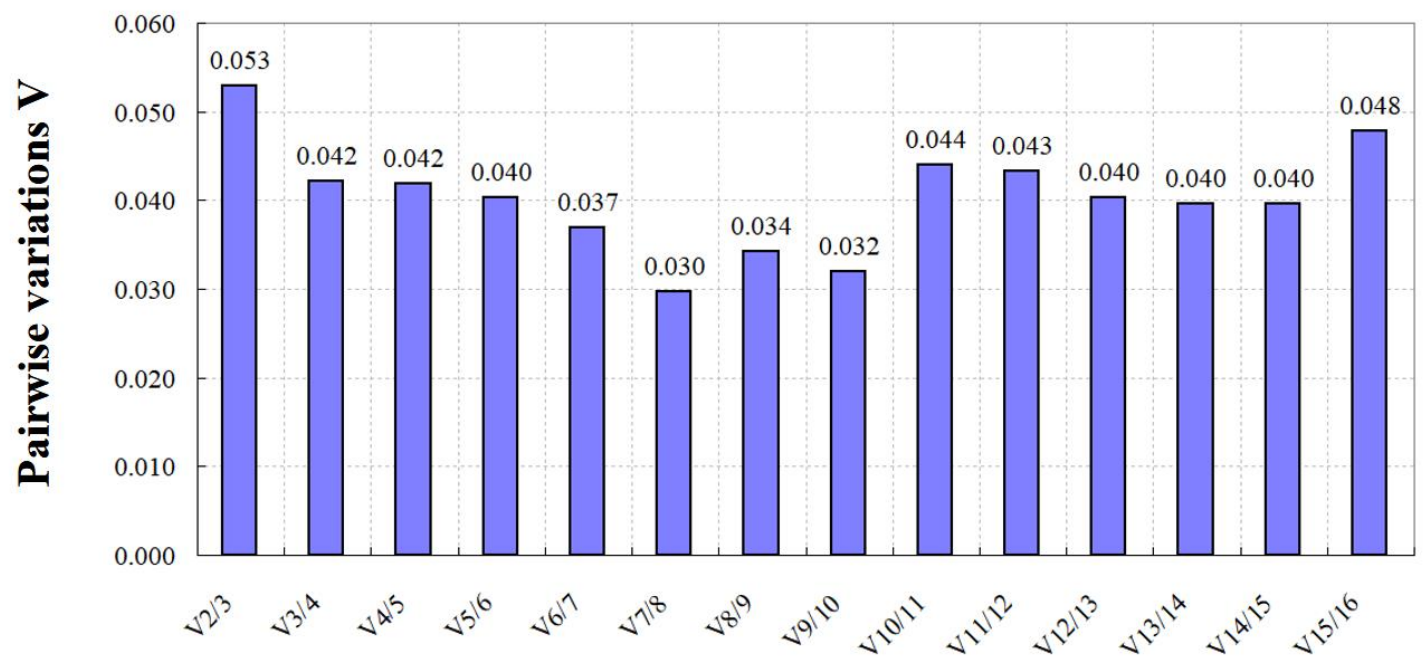

Figure 2. geNorm analysis of the expression stability of the 16 selected RGs. (A) The average expression stability measure (M) and ranking of the candidate RGs were calculated using geNorm. A lower M value indicated a more stable expression. (B) Determination of the optimal number of RGs for normalization by the pairwise variation (V) as assessed using geNorm. The optimal number of RGs was indicated by V values below 0.15 [34]. 


\subsection{Expression Stability of the RGs Assessed via NormFinder Analysis}

As analyzed using the geNorm method, the RGs with the lowest $M$ values were considered to be the most stable. Based on the results of NormFinder analysis, the stabilities of 16 candidate RGs were ranked (Figure 3). RPS4X was the most stable gene, with a stability value less than 0.1 , followed by RPL7, RPS6, RPS26, RPS27A, RPL3, RPS20, and DYNLL1, while GAPT4, ACTB, CALM2, HMBS, FTH1, and GAPDH were the six least stable RGs.

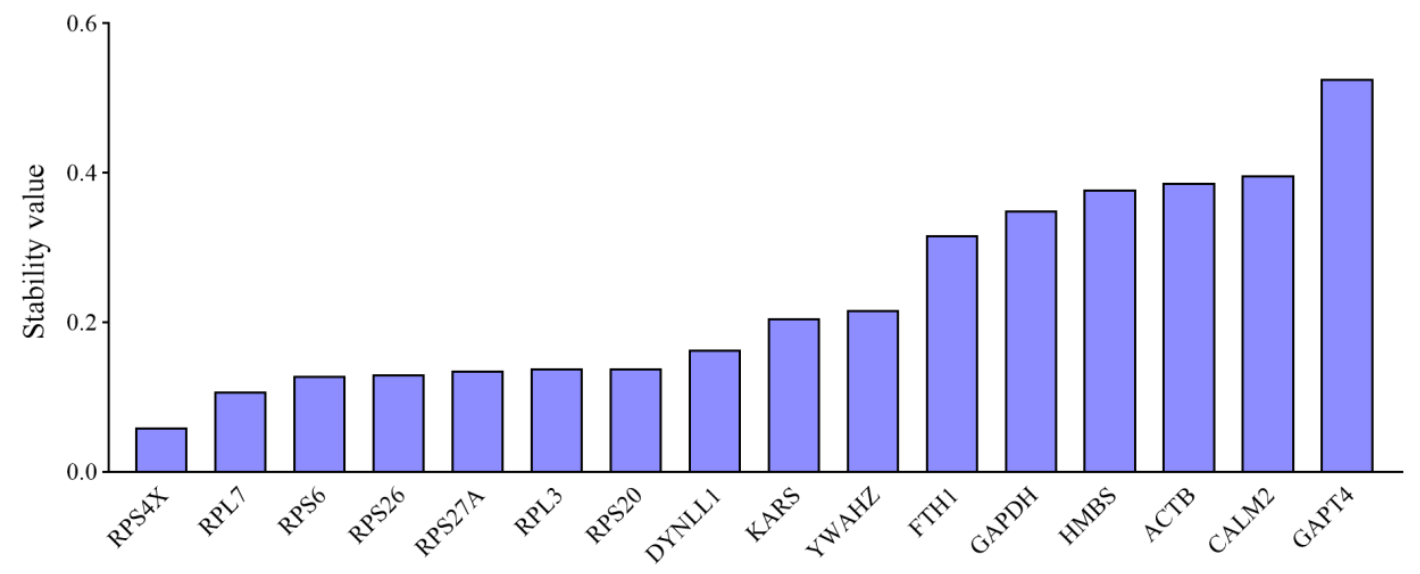

Figure 3. Expression stability of RGs according to NormFinder analysis.

\subsection{Expression Stability of the RGs Assessed via Bestkeeper Analysis}

The most stable RGs were selected based on the lowest coefficient of variance and standard deviation. BestKeeper can only calculate the RGs within 10 numbers. Therefore, the six least stable RGs (GAPT4, ACTB, CALM2, HMBS, FTH1, and GAPDH) were excluded by combining the results of GeNorm and NormFinder. In the 10 RGs that remained, RPS4X and RPS6 were stably expressed in all the samples (Table 2).

Table 2. Expression stability of RGs according to Bestkeeper analysis.

\begin{tabular}{ccccc}
\hline Gene Symbol & SD & CV & r & Rank Order \\
\hline RPS4X & 0.33 & 1.79 & 0.973 & 1 \\
RPS6 & 0.38 & 2.15 & 0.943 & 2 \\
DYNLL1 & 0.36 & 1.71 & 0.930 & 3 \\
RPL7 & 0.31 & 1.75 & 0.917 & 5 \\
RPS20 & 0.36 & 2.05 & 0.916 & 6 \\
RPL3 & 0.37 & 2.03 & 0.914 & 7 \\
RPS26 & 0.35 & 1.99 & 0.889 & 8 \\
RPS27A & 0.26 & 1.49 & 0.872 & 9 \\
YWAHZ & 0.33 & 1.58 & 0.794 & 10 \\
KARS & 0.32 & 1.46 & 0.730 & \\
\hline
\end{tabular}

standard deviation (SD); coefficient of variance (CV); correlation coefficient (r).

\subsection{Normalizing the Expression Profiles of Target Genes Using the Target RGs}

To further verify the selection of candidate RGs, the most stable RGs (RPS4X and RPS6) or the least stable RGs (GAPDH and ACTB) were used to standardize the same target. When IGF1 and TOP2A were normalized using RPS4X and RPS6 as internal RGs, there was a significant difference between the expression levels of IGF1 and TOP2A in the rumen tissues from 2-month-old and 1-year-old goats (Figure 4). In contrast, when the data were normalized to $G A P D H$ and $A C T B$, there was no significant difference in the expression levels of IGF1 and TOP2A. 
A

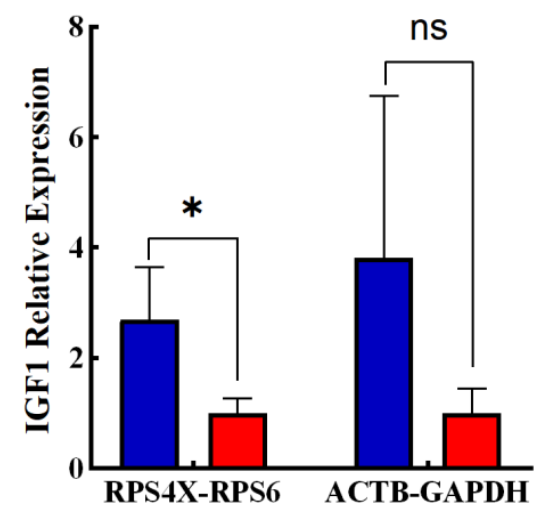

B

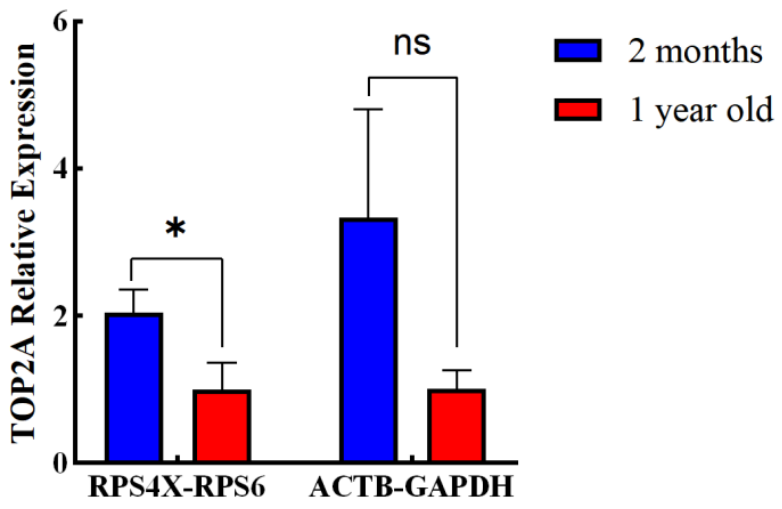

Figure 4. The relative expressions of IGF1 (A) and TOP2A (B) normalized to the different RGs combinations (the most stable RPS4X and RPS6, and the least stable GAPDH and ACTB) using rumen tissues sampled at two developmental stages. * $p<0.05$. "ns" means no significant difference between the two groups.

\section{Discussion}

A large proportion of RGs were selected according to previous literature, of which many were housekeeping genes (HKGs) [7,36,37]. Moreover, it is widely accepted that the expression levels of HKGs are not stable in some species or tissues, and cannot meet the criteria of RG normalization [38-40]. With the development of high-throughput sequencing technology, the selection strategy of RGs based on genome-wide analysis has become more powerful. Seven novel RGs, including RPS4X, were verified to be more stable than the traditional RGs ( $A C T B$ and GAPDH) in the luteal corpus of Holstein cattle during early gestation and luteolysis [41]. In the skin tissues from Chinese indigenous goats, a RG set consisting of NCBP3, SDHA, and PTPRA were filtered out using transcriptome data and displayed more stable expression than previously used HKGs [30]. Similarly, our results based on genome-wide data analysis also show that a new set of candidate genes, RPS4X and RPS6, are more stable in expression than ACTB and GAPDH, suggesting that the traditional RGs may not be ideal RGs, especially for the gene expression assay used in goat rumen tissues.

In ruminants, the digestion and absorption of nutrients occurs mainly in the rumen and small intestine. Carbohydrates are degraded into volatile fatty acids and absorbed by the rumen epithelial cells [29]. Many studies have reported related gene expression profiles during rumen development in goats [24,28,42-44]. To date, few studies have assessed the applicability of HKG standardization in this tissue, and the identification of RGs has not been based on genome-wide identification. Therefore, we conducted a genome-wide analysis of RGs in rumen tissues of goats using our previous RNA sequencing data (rumen tissuess sampled at four developmental stages) and identified a total of 71 potentially stable genes in the study. Eight putative RGs were selected through functional enrichment analysis, all of which belonged to the ribosomal protein gene family except KARS. KARS is a member of the RAS protein family, which is mainly involved in cell proliferation [45,46]. KARS encodes both cytoplasmic and mitochondrial lysyl-tRNA synthetase, a moonlighting protein that has a typical function in protein synthesis [47,48]. In addition, eight genes were selected from the previously reported literature [29,49], including two traditional RGs (ACTB and GAPDH). The stability of these 16 candidate RGs was analyzed by RT-qPCR, and 10 genes were identified to be more stable in rumen development than $A C T B$ and GAPDH. After a comprehensive analysis of the stability of these candidate RGs and the normalization effect of target genes, we concluded that RPS4X and RPS6 was the most stable combination of RGs during rumen development, suggesting that the ribosomal protein gene family might be another RG source. 
Ribosomal proteins play important housekeeping roles in ribosomal biogenesis and protein production and are essential for cell growth, proliferation, differentiation, and development in animals $[50,51]$. Some ribosomal proteins have been shown to play critical roles in tightly coordinating $p 53$ signaling with ribosomal biogenesis. RPS27A and RPS20, for example, interact with the central acid domain of MDM2 and inhibit MDM2-mediated p53 ubiquitination, mediating p53 activation and cell cycle arrest [52,53]. In addition, mutations in the ribosomal protein genes have been found to be involved in cancers such as endometrial cancer (RPL22), chronic lymphoblastic leukemia (RPS15), colorectal cancer (RPS20), and glioma (RPL5) [54]. Phosphorylation of RPS6 attenuates DNA damage and p53-mediated tumor suppression during pancreatic cancer development [55]. RPS4X and RPS4Y encode different subtypes of the RPS4. RPS4, a cysteine protease [56], has been poorly studied. It has been suggested that loss of RPS4 expression may be associated with the development of Turner syndrome (congenital ovarian hypoplasia) [57]. We demonstrate that the ribosomal protein genes (RPS4X and RPS6) were expressed stably during rumen development in goats. Thus, it can be seen that ribosomal protein-coding genes play a critical role in cell life activities, animal growth, and development, and may be an important source of housekeeping genes.

\section{Conclusions}

To verify normalized gene expression in rumen tissues of goats, we identified 16 candidate RGs using the three tools (geNorm, NormFinder, and BestKeeper) based on transcriptome sequencing. We demonstrated that the expression of the RGs (RPS4X and RPS6) selected are more stable than the commonly used HKGs (ACTB and GAPDH) in goat rumen tissues collected at different developmental stages, suggesting that the ribosomal protein gene family may be another source of RGs. This study provides a new idea for screening internal reference genes.

Supplementary Materials: The following are available online at https://www.mdpi.com/article/ 10.3390/ani11113137/s1, Table S1: The stably expressed genes identified in the goat rumens by RNA-sequencing, Table S2: RNA quality of the samples used in this study, Figure S1: Agarose gel electrophoresis for the candidate reference genes, Figure S2: Gradient dissolution curves of reference genes, Figure S3: Standard curves of reference genes, Figure S4: The relative expression of IGF1 and TOP2A normalized to the different RGs. ${ }^{*} p<0.05,{ }^{* *} p<0.01$.

Author Contributions: T.Z. and L.N. conceived and designed the experiments. J.Z. and C.W. performed the experiments. J.Z., C.W., A.L., J.G. and J.C. analyzed the data. L.Z., L.W., S.Z., L.L. and H.Z. participated in sample collection. H.Z., L.N. and T.Z. contributed reagents/materials. J.Z. and T.Z. wrote the manuscript. All authors have read and agreed to the published version of the manuscript.

Funding: This work was supported by the grant from National Natural Science Foundation of China (31802086).

Institutional Review Board Statement: All experiments involving animals were performed in accordance with the Animal management regulations revised by the Ministry of Science and Technology in March 2017 and approved by the Animal Care and Use Committee of the Institute of Animal Science and Technology, Sichuan Agricultural University, Chengdu, China, under the permit number DKY-2020202035.

Informed Consent Statement: Not applicable.

Data Availability Statement: Data sharing is not applicable to this article.

Acknowledgments: Thanks to the Chengdu Xilingxue Agricultural Development Co., Ltd. (Sichuan, China) for providing experimental materials for this study. Thanks to the two reviewers for their comments and editorial assistance.

Conflicts of Interest: The authors declare no conflict of interest. 


\section{References}

1. Piazza, V.G.; Bartke, A.; Miquet, J.G.; Sotelo, A.I. Analysis of Different Approaches for the Selection of Reference Genes in RT-qPCR Experiments: A Case Study in Skeletal Muscle of Growing Mice. Int. J. Mol. Sci. 2017, 18, 1060. [CrossRef] [PubMed]

2. Vandesompele, J.; De Preter, K.; Pattyn, F.; Poppe, B.; Van Roy, N.; De Paepe, A.; Speleman, F. Accurate normalization of real-time quantitative RT-PCR data by geometric averaging of multiple internal control genes. Genome Biol. 2002, 3, 0034.1-0034.11. [CrossRef] [PubMed]

3. Shakeel, M.; Rodriguez, A.; Tahir, U.B.; Jin, F. Gene expression studies of reference genes for quantitative real-time PCR: An overview in insects. Biotechnol. Lett. 2018, 40, 227-236. [CrossRef]

4. Zárybnický, T.; Matoušková, P.; Ambrož, M.; Šubrt, Z.; Skálová, L.; Boušová, I. The Selection and Validation of Reference Genes for mRNA and microRNA Expression Studies in Human Liver Slices Using RT-qPCR. Genes 2019, 10, 763. [CrossRef] [PubMed]

5. Kang, Y.; Wu, Z.; Cai, D.; Lu, B. Evaluation of reference genes for gene expression studies in mouse and N2a cell ischemic stroke models using quantitative real-time PCR. BMC Neurosci. 2018, 19, 3. [CrossRef]

6. Pfaffl, M.W.; Tichopad, A.; Prgomet, C.; Neuvians, T.P. Determination of stable housekeeping genes, differentially regulated target genes and sample integrity: BestKeeper-Excel-based tool using pair-wise correlations. Biotechnol. Lett. 2004, 26, 509-515. [CrossRef] [PubMed]

7. Dunislawska, A.; Slawinska, A.; Siwek, M. Validation of the Reference Genes for the Gene Expression Studies in Chicken DT40 Cell Line. Genes 2020, 11, 372. [CrossRef]

8. Smits, K.; Goossens, K.; Van Soom, A.; Govaere, J.; Hoogewijs, M.; Vanhaesebrouck, E.; Galli, C.; Colleoni, S.; Vandesompele, J.; Peelman, L. Selection of reference genes for quantitative real-time PCR in equine in vivo and fresh and frozen-thawed in vitro blastocysts. BMC Res. Notes 2009, 2, 246. [CrossRef] [PubMed]

9. Lee, P.D.; Sladek, R.; Greenwood, C.M.; Hudson, T.J. Control genes and variability: Absence of ubiquitous reference transcripts in diverse mammalian expression studies. Genome Res. 2002, 12, 292-297. [CrossRef]

10. Panina, Y.; Germond, A.; Masui, S.; Watanabe, T.M. Validation of Common Housekeeping Genes as Reference for qPCR Gene Expression Analysis During iPS Reprogramming Process. Sci. Rep. 2018, 8, 8716. [CrossRef] [PubMed]

11. Abuna, R.P.F.; Oliveira, F.S.; Ramos, J.I.R.; Lopes, H.B.; Freitas, G.P.; Souza, A.T.P.; Beloti, M.M.; Rosa, A.L. Selection of reference genes for quantitative real-time polymerase chain reaction studies in rat osteoblasts. J. Cell Physiol. 2018, 234, 749-756. [CrossRef] [PubMed]

12. de Jonge, H.J.; Fehrmann, R.S.; de Bont, E.S.; Hofstra, R.M.; Gerbens, F.; Kamps, W.A.; de Vries, E.G.; van der Zee, A.G.; te Meerman, G.J.; ter Elst, A. Evidence based selection of housekeeping genes. PLoS ONE 2007, 2, e898. [CrossRef] [PubMed]

13. Dheda, K.; Huggett, J.F.; Chang, J.S.; Kim, L.U.; Bustin, S.A.; Johnson, M.A.; Rook, G.A.; Zumla, A. The implications of using an inappropriate reference gene for real-time reverse transcription PCR data normalization. Anal. Biochem. 2005, 344, 141-143. [CrossRef] [PubMed]

14. Kozera, B.; Rapacz, M. Reference genes in real-time PCR. J. Appl. Genet. 2013, 54, 391-406. [CrossRef] [PubMed]

15. Wang, G.; Chen, Y.; Zhang, X.; Bai, B.; Yan, H.; Qin, D.; Xia, Q. Selection of reference genes for tissue/organ samples on day 3 fifth-instar larvae in silkworm, Bombyx mori. Arch. Insect. Biochem. Physiol. 2018, 98, e21458. [CrossRef] [PubMed]

16. Zhang, C.; Wang, Y.Q.; Jin, G.; Wu, S.; Cui, J.; Wang, R.F. Selection of reference genes for gene expression studies in human bladder cancer using SYBR-Green quantitative polymerase chain reaction. Oncol. Lett. 2017, 14, 6001-6011. [CrossRef] [PubMed]

17. Nascimento, T.V.C.; Oliveira, R.L.; Menezes, D.R.; de Lucena, A.R.F.; Queiroz, M.; Lima, A.; Ribeiro, R.D.X.; Bezerra, L.R. Effects of condensed tannin-amended cassava silage blend diets on feeding behavior, digestibility, nitrogen balance, milk yield and milk composition in dairy goats. Animal 2021, 15, 100015. [CrossRef]

18. Bowen, J.M.; Cormican, P.; Lister, S.J.; McCabe, M.S.; Duthie, C.A.; Roehe, R.; Dewhurst, R.J. Links between the rumen microbiota, methane emissions and feed efficiency of finishing steers offered dietary lipid and nitrate supplementation. PLoS ONE 2020, 15, e0231759. [CrossRef]

19. Hu, Y.; He, Y.; Gao, S.; Liao, Z.; Lai, T.; Zhou, H.; Chen, Q.; Li, L.; Gao, H.; Lu, W. The effect of a diet based on rice straw cofermented with probiotics and enzymes versus a fresh corn Stover-based diet on the rumen bacterial community and metabolites of beef cattle. Sci. Rep. 2020, 10, 10721. [CrossRef]

20. Stumpff, F.; Martens, H.; Bilk, S.; Aschenbach, J.R.; Gäbel, G. Cultured ruminal epithelial cells express a large-conductance channel permeable to chloride, bicarbonate, and acetate. Pflug. Arch. 2009, 457, 1003-1022. [CrossRef]

21. Yohe, T.T.; Schramm, H.; White, R.R.; Hanigan, M.D.; Parsons, C.L.M.; Tucker, H.L.M.; Enger, B.D.; Hardy, N.R.; Daniels, K.M. Form of calf diet and the rumen. II: Impact on volatile fatty acid absorption. J. Dairy Sci. 2019, 102, 8502-8512. [CrossRef] [PubMed]

22. Kramer, T.; Michelberger, T.; Gürtler, H.; Gäbel, G. Absorption of short-chain fatty acids across ruminal epithelium of sheep. J. Comp. Physiol. B 1996, 166, 262-269. [CrossRef]

23. Müller, F.; Huber, K.; Pfannkuche, H.; Aschenbach, J.R.; Breves, G.; Gäbel, G. Transport of ketone bodies and lactate in the sheep ruminal epithelium by monocarboxylate transporter 1. Am. J. Physiol. Gastrointest. Liver Physiol. 2002, 283, G1139-G1146. [CrossRef] [PubMed]

24. Zhong, T.; Wang, C.; Hu, J.; Chen, X.; Niu, L.; Zhan, S.; Wang, L.; Guo, J.; Cao, J.; Li, L.; et al. Comparison of MicroRNA Transcriptomes Reveals the Association between MiR-148a-3p Expression and Rumen Development in Goats. Animals 2020, 10, 1951. [CrossRef] [PubMed] 
25. Nishihara, K.; Suzuki, Y.; Roh, S. Ruminal epithelial insulin-like growth factor-binding proteins 2, 3, and 6 are associated with epithelial cell proliferation. Anim. Sci. J. 2020, 91, e13422. [CrossRef] [PubMed]

26. Malmuthuge, N.; Liang, G.; Guan, L.L. Regulation of rumen development in neonatal ruminants through microbial metagenomes and host transcriptomes. Genome Biol. 2019, 20, 172. [CrossRef] [PubMed]

27. Do, D.N.; Dudemaine, P.L.; Fomenky, B.E.; Ibeagha-Awemu, E.M. Integration of miRNA weighted gene co-expression network and miRNA-mRNA co-expression analyses reveals potential regulatory functions of miRNAs in calf rumen development. Genomics 2019, 111, 849-859. [CrossRef]

28. Zhong, T.; Hu, J.; Xiao, P.; Zhan, S.; Wang, L.; Guo, J.; Li, L.; Zhang, H.; Niu, L. Identification and Characterization of MicroRNAs in the Goat (Capra hircus) Rumen during Embryonic Development. Front. Genet. 2017, 8, 163. [CrossRef]

29. Die, J.V.; Baldwin, R.L.; Rowland, L.J.; Li, R.; Oh, S.; Li, C.; Connor, E.E.; Ranilla, M.J. Selection of internal reference genes for normalization of reverse transcription quantitative polymerase chain reaction (RT-qPCR) analysis in the rumen epithelium. PLoS ONE 2017, 12, e0172674. [CrossRef]

30. Zhang, J.; Deng, C.; Li, J.; Zhao, Y. Transcriptome-based selection and validation of optimal house-keeping genes for skin research in goats (Capra hircus). BMC Genom. 2020, 21, 493. [CrossRef]

31. China National Commission of Animal Genetic Resources. Animal Genetic Resources in China: Sheep and Goats; China Agricultural Press: Beijing, China, 2011; pp. 339-342.

32. Li, D.; Hu, B.; Wang, Q.; Liu, H.; Pan, F.; Wu, W. Identification and Evaluation of Reference Genes for Accurate Transcription Normalization in Safflower under Different Experimental Conditions. PLoS ONE 2015, 10, e0140218. [CrossRef]

33. Dhayat, S.A.; Abdeen, B.; Köhler, G.; Senninger, N.; Haier, J.; Mardin, W.A. MicroRNA-100 and microRNA-21 as markers of survival and chemotherapy response in pancreatic ductal adenocarcinoma UICC stage II. Clin. Epigenetics 2015, 7, 132. [CrossRef]

34. Andersen, C.L.; Jensen, J.L.; Ørntoft, T.F. Normalization of real-time quantitative reverse transcription-PCR data: A model-based variance estimation approach to identify genes suited for normalization, applied to bladder and colon cancer data sets. Cancer Res. 2004, 64, 5245-5250. [CrossRef]

35. Cocci, P.; Mosconi, G.; Palermo, F.A. Changes in expression of microRNA potentially targeting key regulators of lipid metabolism in primary gilthead sea bream hepatocytes exposed to phthalates or flame retardants. Aquat. Toxicol. 2019, 209, 81-90. [CrossRef] [PubMed]

36. Wu, X.; Zhou, X.; Ding, X.; Chu, M.; Liang, C.; Pei, J.; Xiong, L.; Bao, P.; Guo, X.; Yan, P. Reference gene selection and myosin heavy chain (MyHC) isoform expression in muscle tissues of domestic yak (Bos grunniens). PLoS ONE 2020, 15, e0228493. [CrossRef]

37. Zhu, W.; Lin, Y.; Liao, H.; Wang, Y. Selection of reference genes for gene expression studies related to intramuscular fat deposition in Capra hircus skeletal muscle. PLoS ONE 2015, 10, e0121280. [CrossRef] [PubMed]

38. Li, X.; Huang, K.; Chen, F.; Li, W.; Sun, S.; Shi, X.E.; Yang, G. Verification of suitable and reliable reference genes for quantitative real-time PCR during adipogenic differentiation in porcine intramuscular stromal-vascular cells. Animal 2016, 10, 947-952. [CrossRef] [PubMed]

39. Najafpanah, M.J.; Sadeghi, M.; Bakhtiarizadeh, M.R. Reference genes selection for quantitative real-time PCR using RankAggreg method in different tissues of Capra hircus. PLoS ONE 2013, 8, e83041. [CrossRef]

40. Tsotetsi, T.N.; Collins, N.E.; Oosthuizen, M.C.; Sibeko-Matjila, K.P. Selection and evaluation of housekeeping genes as endogenous controls for quantification of mRNA transcripts in Theileria parva using quantitative real-time polymerase chain reaction (qPCR). PLoS ONE 2018, 13, e0196715. [CrossRef] [PubMed]

41. Mezera, M.A.; Li, W.; Edwards, A.J.; Koch, D.J.; Beard, A.D.; Wiltbank, M.C. Identification of stable genes in the corpus luteum of lactating Holstein cows in pregnancy and luteolysis: Implications for selection of reverse-transcription quantitative PCR reference genes. J. Dairy Sci. 2020, 103, 4846-4857. [CrossRef]

42. Pan, X.; Li, Z.; Li, B.; Zhao, C.; Wang, Y.; Chen, Y.; Jiang, Y. Dynamics of rumen gene expression, microbiome colonization, and their interplay in goats. BMC Genom. 2021, 22, 288. [CrossRef] [PubMed]

43. Dai, H.; Liu, X.; Yan, J.; Aabdin, Z.U.; Bilal, M.S.; Shen, X. Sodium Butyrate Ameliorates High-Concentrate Diet-Induced Inflammation in the Rumen Epithelium of Dairy Goats. J. Agric. Food Chem. 2017, 65, 596-604. [CrossRef]

44. Abecia, L.; Jiménez, E.; Martínez-Fernandez, G.; Martín-García, A.I.; Ramos-Morales, E.; Pinloche, E.; Denman, S.E.; Newbold, C.J.; Yáñez-Ruiz, D.R. Natural and artificial feeding management before weaning promote different rumen microbial colonization but not differences in gene expression levels at the rumen epithelium of newborn goats. PLoS ONE 2017, 12, e0182235. [CrossRef] [PubMed]

45. Lechuga, C.G.; Simón-Carrasco, L.; Jacob, H.K.; Drosten, M. Genetic Validation of Cell Proliferation via Ras-Independent Activation of the Raf/Mek/Erk Pathway. Methods Mol. Biol. 2017, 1487, 269-276. [CrossRef]

46. Mattox, T.E.; Chen, X.; Maxuitenko, Y.Y.; Keeton, A.B.; Piazza, G.A. Exploiting RAS Nucleotide Cycling as a Strategy for Drugging RAS-Driven Cancers. Int. J. Mol. Sci. 2019, 21, 141. [CrossRef]

47. Ribó, P.; Guo, Y.; Aranda, J.; Ainsua-Enrich, E.; Navinés-Ferrer, A.; Guerrero, M.; Pascal, M.; de la Cruz, C.; Orozco, M.; MuñozCano, R.; et al. Mutation in KARS: A novel mechanism for severe anaphylaxis. J. Allergy Clin. Immunol. 2021, 147, 1855-1864.e9. [CrossRef] [PubMed]

48. Wang, Y.; Zhou, J.B.; Zeng, Q.Y.; Wu, S.; Xue, M.Q.; Fang, P.; Wang, E.D.; Zhou, X.L. Hearing impairment-associated KARS mutations lead to defects in aminoacylation of both cytoplasmic and mitochondrial tRNA(Lys). Sci. China Life Sci. 2020, 63, 1227-1239. [CrossRef] 
49. Macabelli, C.H.; Ferreira, R.M.; Gimenes, L.U.; de Carvalho, N.A.; Soares, J.G.; Ayres, H.; Ferraz, M.L.; Watanabe, Y.F.; Watanabe, O.Y.; Sangalli, J.R.; et al. Reference gene selection for gene expression analysis of oocytes collected from dairy cattle and buffaloes during winter and summer. PLoS ONE 2014, 9, e93287. [CrossRef] [PubMed]

50. Zhou, X.; Liao, W.J.; Liao, J.M.; Liao, P.; Lu, H. Ribosomal proteins: Functions beyond the ribosome. J. Mol. Cell Biol. 2015, 7, 92-104. [CrossRef]

51. Petibon, C.; Malik, G.M.; Catala, M.; Abou, E.S. Regulation of ribosomal protein genes: An ordered anarchy. Wiley Interdiscip. Rev. RNA 2021, 12, e1632. [CrossRef]

52. Daftuar, L.; Zhu, Y.; Jacq, X.; Prives, C. Ribosomal proteins RPL37, RPS15 and RPS20 regulate the Mdm2-p53-MdmX network. PLoS ONE 2013, 8, e68667. [CrossRef]

53. Xiong, X.; Zhao, Y.; He, H.; Sun, Y. Ribosomal protein S27-like and S27 interplay with p53-MDM2 axis as a target, a substrate and a regulator. Oncogene 2011, 30, 1798-1811. [CrossRef]

54. Goudarzi, K.M.; Lindström, M.S. Role of ribosomal protein mutations in tumor development (Review). Int. J. Oncol. 2016, 48, 1313-1324. [CrossRef]

55. Khalaileh, A.; Dreazen, A.; Khatib, A.; Apel, R.; Swisa, A.; Kidess-Bassir, N.; Maitra, A.; Meyuhas, O.; Dor, Y.; Zamir, G. Phosphorylation of ribosomal protein $\mathrm{S} 6$ attenuates DNA damage and tumor suppression during development of pancreatic cancer. Cancer Res. 2013, 73, 1811-1820. [CrossRef]

56. Sudhamalla, B.; Kumar, M.; Roy, K.R.; Kumar, R.S.; Bhuyan, A.K. Cysteine endoprotease activity of human ribosomal protein S4 is entirely due to the C-terminal domain, and is consistent with Michaelis-Menten mechanism. Biochim. Biophys. Acta 2013, 1830, 5342-5349. [CrossRef]

57. Zinn, A.R.; Alagappan, R.K.; Brown, L.G.; Wool, I.; Page, D.C. Structure and function of ribosomal protein S4 genes on the human and mouse sex chromosomes. Mol. Cell Biol. 1994, 14, 2485-2492. [CrossRef] 